\title{
Fenomenologie van het proces van bewijzen in strafzaken
}

\section{Over de noodzaak van het vooroordeel}

\author{
Thomas Jacobus de Jong
}

\section{Inleiding}

Zonder waarheid geen rechtvaardigheid. De waarheidsvinding speelt dan ook een centrale rol in het recht. Daarbij geldt als algemeen gedeeld uitgangspunt dat de waarheid nooit absoluut, definitief of af is, maar slechts bij benadering kan worden vastgesteld. Zoals de beroemde uitspraak van de Duitse verlichtingsdenker Lessing luidt: 'niet het bezit maar de navorsing van de waarheid' is het bereik en doel van het menselijk streven. ${ }^{1}$ Het navorsen van de waarheid houdt in het kader van het recht ten nauwste verband met het vergaren van bewijsmateriaal. De beoordeling van het waarheidsgehalte van gepresenteerde feiten wordt gemaakt aan de hand van het beschikbare bewijs - 'Evidence is the basis of justice'2. Dat geldt in zeer sterke mate voor het strafrecht, waarin de materiële waarheidsvinding wordt gefilterd van rechtens irrelevante feiten en gebeurtenissen. Het probandum (hetgeen bewezen moet worden) fungeert hier als een trechter, die de historische werkelijkheid reduceert tot de onderdelen die gelet op de tenlastelegging van belang worden geacht (de materiële waarheid). ${ }^{3}$ Uiteindelijk draait het in het strafrechtelijk onderzoek in de kern om de vraag of het tenlastegelegde kan worden bewezen. De strafrechtelijke waarheidsvinding is derhalve vooral gericht op bewijsgaring. ${ }^{4}$

Vanuit dit oogpunt is het verwonderlijk dat in het Nederlandse strafprocesrecht geen omvattende bewijstheorie over het selecteren en waarderen van bewijs is ontwikkeld..$^{5}$ In andere wetenschappelijke disciplines zijn op dit terrein daarentegen wel stappen gezet. Globaal beschouwd kunnen drie (niet-juridische) bewijstheorieën worden onderscheiden: (1) de argumentatieve benadering, (2) bewijzen

1 Zie Gotthold E. Lessing, Eine Duplik. Gotthold Ephraim Lessings sämtliche Schriften (Leipzig: Karl Lachmann, 1897), 23-24.

2 Jeremy Bentham, The Works of Jeremy Bentham, vol. 7 (Rationale of Judicial Evidence), boek IX, hfdst. III, openbaar toegankelijk op <http://oll.libertyfund.org/titles/bentham-the-works-ofjeremy-bentham-vol-7-rationale-of-judicial-evidence-part-2>.

3 Vgl. Jan H. Crijns, 'Een kroniek van de strafrechtelijke waarheidsvinding,' in De waarde van waarheid: opstellen over waarheid en waarheidsvinding in het strafrecht, red. Jan H. Crijns et al. (Den Haag: Boom Juridische uitgevers, 2008), 51.

4 Zie ook Henk G. van de Bunt, 'De onderste steen; enkele kanttekeningen bij het primaat van het strafrecht in de waarheidsvinding,' in Justitiële Verkenningen 4, nr. 44 (2002): 13.

5 Zie ook Marieke J. Dubelaar, 'Betrouwbaar getuigenbewijs. Totstandkoming en waardering van strafrechtelijke getuigenverklaringen in perspectief' (PhD diss., Universiteit Leiden, 2014), 214-15. 
door verankering van een verhaal en (3) de rekenkundige methode naar het model van de Bayesiaanse kansrekening. ${ }^{6}$ Ondanks de verschillen gaan al deze theorieën in meer of mindere mate uit van de basale notie dat de activiteit van bewijzen primair een rationeel regelgeleid proces is en vooral ook behoort te zijn. Vergelijkbaar met de empirische wetenschappen dienen de feiten in een strafzaak zo veel mogelijk objectief te worden vastgesteld aan de hand van het beschikbare bewijsmateriaal. Met als doelstelling de onbevooroordeelde reconstructie van een deel van de historische werkelijkheid.

In deze bijdrage wil ik betogen dat deze rationalistische opvatting van de activiteit van bewijzen eraan voorbijgaat dat het bewijzen zich allereerst voltrekt op een vóór-reflectief niveau. Het primaire blikveld van de mens is niet het objectiverende kennen, zoals in de rationele bewijstheorieën wordt voorondersteld, maar de praktische relatie tot de wereld. Elke rationele en conceptuele omgang met bewijs is daarom afgeleid van een praktisch voor-reflectief begrijpen van de werkelijkheid. Ter onderbouwing van dit standpunt zal ik gebruik maken van ideeën en inzichten die zijn ontleend aan de existentiële fenomenologie. Dit betreft een wijsgerige methode die als doel heeft de werkelijkheid te beschrijven vanuit de wijze waarop deze in de concrete ervaring verschijnt, onafhankelijk van allerlei theoretische constructies.

Hiertoe wil ik eerst in het kort de overeenkomsten en verschillen tussen de genoemde bewijstheorieën bespreken. Daarna zal een aantal filosofische inzichten en noties achter de rationalistische opvatting van bewijzen worden uitgelicht, met bijzondere aandacht voor Aristoteles en Descartes. Tegen deze achtergrond zal aan de hand van de existentiële fenomenologie de rationalistische bewijsopvatting kritisch worden geherwaardeerd.

\section{Redeneren en argumenteren met bewijs}

\subsection{Het proces van bewijzen}

Binnen de wetenschappelijke bestudering van het bewijs in strafzaken kan een schematisch onderscheid worden gemaakt tussen rechtsvragen en vragen die verband houden met de vaststelling van de feiten. Het strafrechtelijk bewijsrecht wordt aangedreven door vragen van de eerste snit, waarbij het gaat om de constitutie en uitleg van bewijsregels. In juridische opleidingen wordt hoofdzakelijk vanuit bewijsrechtelijk perspectief tegen bewijs aangekeken. Onder invloed van de Anglo-Amerikaanse 'new evidence scholarship' is er echter sinds enkele decennia onder Nederlandse juristen en wetenschappers een toenemende belangstelling voor het redeneren over vragen van feitelijke aard in het kader van een strafzaak. Dat wil zeggen het 'proces van bewijzen' en dan met name in relatie tot pro-

6 Henry Prakken, 'Strafrechtelijk bewijzen: met Bayes of met verhalen? Of is er een derde weg?' Expertise en Recht 1 (2014): 4. 
babiliteit. ${ }^{7}$ Kenmerkend voor deze koersverschuiving is dat vanuit diverse disciplines wordt onderzocht hoe redeneren en argumenteren met bewijs behoort te worden betracht. Daarbij kunnen au fond de drie eerder genoemde bewijstheorieën worden onderscheiden, die ieder afzonderlijk voortkomen uit een niet-juridische tak van sport. Deze theorieën zijn in de eerste plaats normatief van aard; ze schrijven voor wat op grond van het bewijsmateriaal een juiste redenering of argument oplevert. Desalniettemin claimen de meeste aanhangers van deze theorieën dat deze tot op zekere hoogte beschrijven hoe het er in de praktijk aan toegaat. $^{8}$

Hoewel de theorieën op een aantal punten wezenlijk van elkaar verschillen, hebben zij een gemeenschappelijk oogmerk. Alle drie zijn uiteindelijk gericht op het realiseren van de hoofddoelstelling van het strafproces: de juiste toepassing van het materiële strafrecht. ${ }^{9}$ Dat wil zeggen, een toepassing die uitgaat van hetgeen werkelijk is voorgevallen voor zover dit gelet op de tenlastelegging van belang is. Een dergelijk streven ligt eveneens ten grondslag aan wat in de AngloAmerikaanse literatuur over bewijzen te boek staat als de 'rationalistische traditie'. ${ }^{10}$ Binnen deze traditie wordt de juridische waarheidsvinding gekarakteriseerd als een rationeel proces met rationeel bewijs als zijn centrale idee. Daarbij geldt de correspondentietheorie van de waarheid als ijkpunt en inductie als de redeneervorm bij uitstek om tot die waarheid te geraken. Evenwel met de belangrijke kanttekening dat waarheidsvinding bij gebreke aan absolute zekerheid slechts kan leiden tot waarschijnlijkheidsuitspraken, die zijn geworteld in onze algemene kennis van de wereld. Deze grondtrekken behoren tot de essentie of hoegenaamd de 'redelijke kern' ${ }^{11}$ van de drie heersende bewijstheorieën.

Desalniettemin presenteren de afzonderlijke theorieën een eigen visie op de selectie en waardering van bewijs teneinde uit te komen bij een rationele bewijsbeslissing. In dit opzicht kan een onderscheid worden gemaakt tussen een holistisch en atomistisch perspectief op bewijzen. ${ }^{12}$ Waar in geval van de atomistische benaderingswijze ieder bewijsmiddel afzonderlijk wordt beoordeeld en gewogen en dus bottum-up wordt geredeneerd, is in de holistische benaderingswijze de bewijsconstructie als geheel het vertrekpunt en wordt derhalve top-down geredeneerd.

7 Zie over 'new evidence scholarship' Richard Lempert, 'The New Evidence Scholarship: Analyzing the Process of Proof,' in Probability and Inference in the Law of Evidence: Uses and Limits of Bayesianism, red. Peter Tillers et al. (Dordrecht: Kluwer, 1988), 62-102. Zie ook meer recent: Paul Roberts en Mike Redmayne, Innovations in Evidence and Proof. Integrating Theory, Research and Teaching (Oxford: Hart Publishing, 2007).

8 Zie William L. Twining, Rethinking evidence: exploratory essays (Cambridge: Cambridge University Press, 2006), 278.

9 Vgl. Matthias J. Borgers en Geert J.M. Corstens, Het Nederlands strafprocesrecht (Deventer: Kluwer, 2014), 1.3.

10 William L. Twining, Rethinking Evidence: Exploratory Essays (Cambridge: Cambridge University Press, 2006), 35-86. Zie ook Terence Anderson, David Schum en William L. Twining, Analysis of Evidence (Cambridge: Cambridge University, 2005), 78-111.

11 Deze term is afkomstig van Lon Fuller. Zie Lon. L. Fuller, 'The Forms and Limits of Adjudication,' Harvard Law Review 92 (1978): 306.

12 Twining, Rethinking Evidence, 309. 
Zo dragen de narratieve bewijstheorieën een duidelijk holistisch karakter; het verhaal vormt de context waarin de verschillende bewijsmiddelen betekenis krijgen. In Nederland heeft het narratieve denken over bewijs voet aan de grond gekregen met de door Crombag, Van Koppen en Wagenaar uitgewerkte theorie van verhaal en verankering. Zij baseren zich hierbij op psychologisch onderzoek waaruit blijkt dat de waarheidsvinding in strafzaken wordt gedicteerd door het construeren en vergelijken van verhalen. ${ }^{13}$ Welk verhaal uiteindelijk wordt aangenomen hangt, aldus de onderzoekers, af van twee bepalende 'zekerheidsprincipes'. ${ }^{14}$ Ten eerste dient het verhaal zo veel mogelijk van het voorhanden bewijsmateriaal in aanmerking te nemen. Daarnaast gaat het om de coherentie van het verhaal, dat wil zeggen de mate van consistentie, plausibiliteit en compleetheid. Volgens de theorie van verhaal en verankering toetst een beslisser ${ }^{15}$ het verhaal van de tenlastelegging aan de afzonderlijke bewijsmiddelen, of zou dat in elk geval moeten doen. Daarbij fungeert ieder bewijsmiddel als een deelverhaal, dat uiteindelijk moet worden teruggevoerd en verankerd in algemeen aanvaarde kennis. Hoe dieper de beslisser afdaalt in de hiërarchie van deelverhalen, hoe specifieker en bijgevolg veiliger de algemene vuistregel waarvoor hij voor anker moet gaan. ${ }^{16}$

Het grote gevaar van narratieve bewijstheorieën is dat een goed verhaal een waar verhaal kan verdringen. ${ }^{17}$ Door het verhaal te verankeren in veilige vuistregels wordt dat risico weliswaar gemitigeerd, niettemin appelleert een verhaal dikwijls aan intuïtie en emotie waardoor fouten of zwakten in de bewijsconstructie niet worden opgemerkt of genegeerd. In dat kader wordt door sommige auteurs een complementaire rol toegedacht aan atomistische theorieën. ${ }^{18}$ Zo kan met behulp van de argumentatieve benadering de coherentie van het verhaal worden getoetst door beginnend bij het voorliggende bewijsmateriaal elke stap in de redenering te analyseren en onder te brengen in een omvattend schema. Een bewijsredenering toont zich op die manier als een keten van argumenten; wanneer een schakel zwak is of uitgaat van een onjuiste aanname wordt de keten logischerwijs doorbroken. ${ }^{19}$ Hoewel deze benadering zeer geschikt is om een grote hoeveelheid bewijs te ordenen en te analyseren en daarmee eventuele ondeugdelijke gevolg-

13 Nancy Pennington en Reid Hastie, 'Explaining the Evidence: Tests of the Story Model for Juror Decision Making,' Journal of Personality and Social Psychology 62, nr. 2 (1992): 189-206.

14 Nancy Pennington en Reid Hastie, 'The Story Model for Juror Decision Making,' in Inside the Juror: The Psychology of Juror Decision Making, red. Reid Hastie (Cambridge: Cambridge University Press, 2004), 193.

15 Met deze term wordt in het kader van deze bijdrage gedoeld op zowel de rechter als de officier van justitie.

16 Zie Hans F.M. Crombag. Peter J. van Koppen en Willem A. Wagenaar, Dubieuze zaken. De psychologie van strafrechtelijk bewijs (Amsterdam: Contact (Olympus), 2006), 69-74

17 Zie William L. Bennett en Martha S. Feldman, Reconstructing Reality in the Courtroom: Justice and Judgement in American Culture (London: Methuen-Tavistock, 1981).

18 Zie Floris J. Bex, Peter J. van Koppen en Henry Prakken, 'A Hybrid Formal Theory of Arguments, Stories and Criminal Evidence,' Artificial Intelligence and Law 18, nr. 2 (2010): 123-52 en Anderson, Schum en Twining, Analysis of Evidence, 114.

19 Marijke Malsch en Ian Freckelton, 'The Evaluation of Evidence: Differences between Legal Systems,' in Legal Evidence and Proof: Statistics, Stories, Logic, red. Hendrik Kaptein, Henry Prakken en Bart Verheij (Farnham: Ashgate, 2009), 121. 
trekkingen of ongefundeerde generalisaties aan het licht te brengen, bevat zij geen speciale regels voor de weging van de bewijskracht. ${ }^{20}$ In dat opzicht placht het Bayesiaanse redeneerschema houvast te verschaffen. Met het theorema van Bayes wordt het redeneren met bewijs voorgesteld als een kansverhouding, waarin alternatieve hypothesen tegen elkaar worden afgewogen. Dit betreft eveneens een vorm van atomistische analyse. De bewijskracht of likelihood ratio (LR) van een individueel bewijsmiddel wordt statistisch vastgesteld door te berekenen hoe goed zij aansluit bij ieder van de voorliggende hypothesen. Vervolgens dient de LR te worden vermenigvuldigd met de in een (a priori) kansverhouding uitgedrukte overtuiging voorafgaande aan dat bewijsmiddel (prior odds). De uitkomst van deze som geeft aan hoe waarschijnlijk het is dat de gegeven hypothesen waar zijn (posterior odds). ${ }^{21}$ Een belangrijk voordeel van deze methode is dat zij dwingt om alternatieve hypothesen in ogenschouw te nemen. ${ }^{22}$ De afzonderlijke bewijsmiddelen krijgen immers alleen betekenis in relatie tot twee of meer aan elkaar tegengestelde hypothesen.

\subsection{Deductie, inductie en abductie te midden van de verschijnselen}

De meeste kwesties over bewijs zijn in de kern epistemologisch van aard. Zo schreef de al eerder aangehaalde jurist en filosoof Jeremy Bentham: 'The field of evidence is no other than the field of knowledge. ${ }^{.23}$ Dit vindt ook weerklank in de etymologie van het woord 'bewijzen', dat oorspronkelijk 'wetend maken' betekent. De verhouding tussen bewijs en kennis is voor het eerst door Aristoteles op fundamentele wijze doordacht. Daarmee heeft hij de basis gelegd voor de hiervoor besproken rationalistische traditie in de wetenschappelijke bestudering van feitenonderzoek en bewijs in het recht en de daarop geënte rationele bewijstheorieën. Het is derhalve zinvol hier langer bij stil te staan.

Aristoteles maakt een onderscheid tussen grofweg drie categorieën van kennis: theoretische kennis (epistêmê), technische vaardigheid (technê) en praktische wijsheid (phronêsis). ${ }^{24}$ Deze kennisvormen zijn niet zozeer gekoppeld aan verschillende soorten opgeslagen informatie, maar staan ieder afzonderlijk voor een bepaalde dispositie van de ziel of karakterhouding, die het resultaat is van gewoonte. Theoretische kennis duidt in dit geval op een getrainde dispositie of houding, die iemand in staat stelt bewijzen te leveren of te deduceren. ${ }^{25}$ Het omvat alles wat we tegenwoordig wetenschappelijk inzicht noemen. In dit opzicht stelt Aristoteles dat we denken iets te weten wanneer we denken dat we niet alleen de oorzaak kennen waardoor iets is, maar ook dat het niet anders kan zijn,

David A. Schum, Evidential Foundations of Probabilistic Reasoning (New York: John Wiley \& Sons, 1994), 63.

21 Zie voor een heldere samenvatting van het Bayesiaanse redeneerschema het drieluik 'Bewijs en overtuiging' van Charles Berger en Diederik J.C. Aben in Expertise en Recht 2 (2010): 3, 5 en 6.

22 Berger en Aben, 'Bewijs en overtuiging,' 56.

23 Jeremy Bentham, The works of Jeremy Bentham, vol. 6 (Rationale of Judicial Evidence), hfdst. I.

24 Aristoteles, Metafysica, 1025 b 25.

25 Aristoteles, Ethica Nicomachea, 1139 b 31-32. 
oftewel noodzakelijk is. ${ }^{26}$ De activiteit van bewijzen behoort wezenlijk toe aan het domein van wetenschappelijke kennis. Volgens Aristoteles is bewijs datgene wat wetenschappelijk inzicht oplevert. ${ }^{27}$ Onder bewijs verstaat hij in dit verband een noodzakelijk teken (tekmêrion), waaruit met onomstotelijke zekerheid een conclusie kan worden gededuceerd. ${ }^{28}$ Dit bewijs staat aan de basis van het klassiek syllogisme, waarbinnen het de plaats inneemt van de minorpremisse. Het syllogisme wordt in de Analytica priora, het basiswerk over deductief redeneren, gedefinieerd als een redenering, dat gegeven bepaalde veronderstellingen, iets anders noodzakelijk krachtens deze veronderstellingen voortvloeit. ${ }^{29}$ Een eenvoudig voorbeeld: (major) alle honden zijn dieren, (minor) Lassie is een hond, (conclusio) dus hij is een dier. Dit voorbeeld maakt direct duidelijk dat voor de deductieve redenering geldt dat als de premissen waar zijn het noodzakelijk is dat ook de conclusie waar is.

Het is niet verrassend dat in het proces van strafrechtelijk bewijzen veelvuldig gebruik wordt gemaakt van deductie. De mens heeft nu eenmaal algemene vuistregels nodig teneinde bijzondere observaties door waarnemingen te ordenen en te duiden. In het strafrechtelijk bewijsrecht worden dit algemene ervaringsregels of feiten en omstandigheden van algemene bekendheid genoemd, die zelf geen bewijs behoeven. Dit betreft aldus de Hoge Raad 'gegevens die ieder rechtstreeks bij het geding betrokkenen geacht moet worden te kennen of die hij zonder noemenswaardige moeite uit algemeen toegankelijke bronnen kan achterhalen'. ${ }^{30}$ Enkele voorbeelden hiervan zijn: in de borststreek bevinden zich vitale organen, mensen hebben doorgaans een mobiele telefoon bij zich, een reiziger is over het algemeen op de hoogte van de inhoud van zijn bagage en een nieuwe fiets kost normaliter geen $€ 30$. Alleen het eerstgenoemde feit van algemene bekendheid kan evenwel een noodzakelijke conclusie opleveren. De andere voorbeelden bevatten daarentegen regels die probabilistisch van aard zijn, omdat zij uitzonderingen toelaten. ${ }^{31}$ De daarop gebaseerde deducties zijn derhalve niet noodzakelijk, want aangenomen dat de major- en minorpremissen waar zijn, is de conclusie hooguit waarschijnlijk waar. Dit brengt het gevaar met zich dat een bewijsredenering ten onrechte wordt gestoeld op een vuistregel, omdat de uitzondering van toepassing is. Bovendien is het niet denkbeeldig dat een gegeven te makkelijk als feit van algemene bekendheid wordt aangenomen, teneinde een bewijsprobleem te omzeilen. ${ }^{32}$

Binnen de rationalistische traditie wordt in dit verband - maar in bredere zin gesproken over generalisaties op basis van 'background knowledge' of 'society's 
stock of knowledge'. ${ }^{33}$ Het wordt verondersteld dat de beslisser voorafgaande aan de behandeling van een strafzaak reeds is toegerust met een grote hoeveelheid generalisaties, die op de achtergrond actief zijn bij het redeneren en argumenteren over vragen van feitelijke aard. Generalisaties fungeren in dit opzicht als waarborgen, die als een 'bindmiddel' de gevolgtrekkingen op basis van het bewijs aan het verhaal, argument of de hypothese verbinden. ${ }^{34}$ Gelet op de genoemde gevaren die inherent vastkleven aan de toepassing van generalisaties, dwingen de drie bewijstheorieën de beslisser ertoe om ze expliciet te maken teneinde te toetsen of ze in het voorliggende geval wel van toepassing zijn.

Naast de (quasi) deductie op basis van algemene vuistregels of generalisaties geldt het syllogisme in het kader van de rechtsvinding als de mal waarin de rechterlijke beslissing wordt gegoten. ${ }^{35}$ Hierbij bestaat de majorpremisse uit de rechtsregel, de minorpremisse uit de rechtsfeiten (bewijzen) en de conclusie uit het rechtsgevolg dat gezien de feiten noodzakelijk uit de rechtsregel wordt afgeleid. De rechtsregel bepaalt dus welke feiten wel en niet relevant zijn en vormt samen met het bewijs de rechtvaardiging (legitimatie) van het rechtsgevolg. Zoals Paul Scholten terecht heeft aangevoerd is in de praktijk ook de omgekeerde beweging te zien, waarbij het vinden van de juiste regel en de inhoudelijke invulling daarvan zich in het licht van het geheel van feiten voltrekt - ius in causa positum. ${ }^{36}$ De rechtsvinding laat zich derhalve niet volledig karakteriseren als de syllogistische deductie van rechtsregel en feiten. Want bij de vaststelling van het recht, is de major noch de minor vooraf gegeven, maar is het resultaat van de beslissing. ${ }^{37}$ Denk bijvoorbeeld aan iemand die in een winkel een product in zijn jaszak wegstopt. Het is pas met de beslissing dat dit feit wordt gekwalificeerd als diefstal, waarin een bepaalde interpretatie van de bestanddelen van dit delict ligt besloten.

Ook Aristoteles was reeds van oordeel dat bij het maken van juridische afwegingen de concrete situatie leidend is. De vraag wat goed handelen is valt niet in zijn algemeenheid te beantwoorden, maar laat zich kennen aan de hand van de particularia van een concreet geval. De rechterlijke beslissing berust volgens Aristoteles daarom niet op theoretische kennis, maar komt voort uit een flexibel heen en weer bewegen tussen de algemene norm en concrete feiten. ${ }^{38}$ Dat vereist praktische wijsheid (phronêsis), dat wil zeggen een vorm van kennis die betrekking heeft op het volstrekt concrete en wordt gedragen door in het leven opgebouwde ervaring (empeiria). ${ }^{39}$ Deze wijsheid of prudentie is niet te herleiden tot algemene

33 Zie Anderson, Schum en Twining, Analysis of Evidence, 269.

34 Schum, Evidential Foundations, 81-82.

35 Zie ook Jacob H. Nieuwenhuis, 'Legitimatie en heuristiek van het rechterlijk oordeel,' Rechtsgeleerd Magazijn Themis (1976): 494-515.

36 Paul Scholten, Handleiding tot de beoefening van het Nederlands burgerlijk recht. Algemeen deel (Zwolle: W.E.J. Tjeenk-Willink, 1974), 9-10 en 121.

37 Vgl. Carel Smith, 'Fenomenologie van de gewetensbeslissing: twee varianten,' in Recht, beslissing en geweten, red. Afshin Ellian, Timo Slootweg en Carel Smith (Deventer: Kluwer, 2010), 185-86.

38 Vgl. Martha Nussbaum, De breekbaarheid van het goede. Geluk en ethiek in de Griekse filosofie en literatuur (Amsterdam: Ambo, 2006), 405 en 437.

39 Aristoteles, Ethica Nicomachea, 1142 a 14-16, 24-25. 
regels of onveranderlijke principes, zoals Plato dacht. Het is evenwel een rationele eigenschap, die de mens in een specifieke context volgens waar inzicht doet handelen met betrekking tot wat voor hem goed of slecht is. ${ }^{40}$

Om het goede te vatten is onder andere lange en brede ervaring nodig. Het begrip empeiria is de etymologische oorsprong van het hedendaagse woord 'empirie' en roept als zodanig de associatie op met het positief natuurwetenschappelijke ideaal van waardenvrije en onpersoonlijke observatie. In de vroege Griekse oudheid was een dergelijk positivistisch beeld van theorieneutrale ervaring echter niet bekend. ${ }^{41}$ Aristoteles doelt daarentegen met ervaring op de wijze waarop verschijnselen (phainomena) zich in de dagelijkse omgang vertonen. De ervaring bestaat eigenlijk uit een verzameling van individuele verschijningen van bepaalde objecten, waarvan we een even groot aantal herinneringen bezitten, die worden gecomprimeerd tot één enkel algemeen feit. ${ }^{42} \mathrm{Bij}$ deze individuele verschijningen gaat het om de gangbare overtuigingen en opvattingen (endoxa), die naar voren komen in wat we over een onderwerp zeggen. ${ }^{43}$ Wat aan ons verschijnt bestaat niet onafhankelijk van menselijke tussenkomst, hetgeen John Searle aanduidde met brute facts. ${ }^{44}$ De verschijnselen weerspiegelen volgens Aristoteles juist hoe de menselijke waarnemer daar gewoonlijk tegen aankijkt. De ervaring van de wereld is aldus onlosmakelijk verweven met meningen, zegswijzen en interpretaties. Dit type ervaring is de basis voor elke vorm van kennis.

Hoewel het deductief syllogisme een handig middel is om verworven kennis mee te ordenen, is zij minder geschikt om nieuwe ontdekkingen te doen. In plaats van het bijzondere noodzakelijk uit het algemene af te leiden door middel van bewijzen, wordt in de praktijk doorgaans de omgekeerde weg gevolgd, waarbij bewijzen uit de ervaring worden gewonnen. Aristoteles noemt deze redeneerwijze inductie (epagôgê) en omschrijft het als: 'laten zien dat iets in een aantal gelijksoortige gevallen zo is' ${ }^{45}$ Zo kan uit de observaties van tien zwarte raven worden geconcludeerd dat alle raven zwart zijn. Kenmerkend voor inductie is dat de conclusie verder reikt dan wat is waargenomen, waardoor het aan noodzakelijkheid ontbreekt. De volgende raaf kan immers wit zijn. Aristoteles is echter van oordeel dat inductieve redeneringen evenzeer noodzakelijk kunnen zijn. Daartoe acht hij niet nodig, zoals dikwijls wordt beweerd, dat eerst alle denkbare gevallen moeten zijn waargenomen. Aristoteles was zich terdege bewust dat deze zogeheten volmaakte of complete inductie veelal onmogelijk is. Hij beschouwt inductie dan ook veeleer

40 Aristoteles, Ethica Nicomachea, 1140 b 4-6.

41 Nussbaum, Breekbaarheid van het goede, 349.

42 Zie Aristoteles, Metafysica, 980 27-981a1.

43 Deze interpretatie van phainomena heb ik ontleend aan Nussbaum maar is niet onomstreden. Zie Nussbaum, Breekbaarheid van het goede, 343-71. Nussbaum baseert zich ten dele op het gerenommeerde artikel van Gwilym E.L. Owen 'Tithenai ta Phainomena,' in Aristotle: A Collection of Critical Essays, red. Julius M.E. Moravcsik (New York: Palgrave Macmillan, 1967), 167-90. Zie ook Adam A. Sandel, Ruimte voor vooroordelen. Pleidooi voor betrokken denken (Utrecht: Ten Have, 2015), 253-55.

44 Zie John R. Searle, The Construction of Social Reality (New York: The Free Press, 1995), 2.

45 Zie Aristoteles, Topica, 105 a 10-19 en Rhetorica, 1356 b 14-15. 
als een inzicht dat bestaat uit het herkennen van een noodzakelijke en universele natuur in vergelijkbare gevallen. ${ }^{46}$ Je hoeft niet alle levende zwanen te hebben waargenomen om te kunnen concluderen dat zwanen vleugels hebben. Voor zover inductie is gericht op het blootleggen van fundamentele gelijkenissen of wetmatigheden en niet op toevalligheden, zijn de conclusies volgens Aristoteles evengoed noodzakelijk. Daarbij moet bijzondere waarde worden gehecht aan de meningen en beweringen van ervaren of verstandige mensen, in het bijzonder geleerden en filosofen. ${ }^{47}$ Door hun ervaring zullen zij beter in staat zijn het universele in het bijzondere te herkennen.

Bij het bewijzen in juridische procedures, met name in het strafrecht, speelt inductie een elementaire rol. Dat betreft niet de enumeratieve of opsommende inductie, zoals in het genoemde voorbeeld van de zwanen. In het proces van strafrechtelijk bewijzen wordt op grond van uiteenlopende specifieke informatie een overkoepelende en verderstrekkende conclusie getrokken. Zo kan uit: (a) een aangifte van een juwelier in verband met weggenomen sieraden, (b) een getuige die midden in de nacht iemand met het signalement van verdachte in de buurt van de juwelier heeft zien wegrennen met een zak, (c) het kort daarna in de auto van verdachte aantreffen van deze zak gevuld met de ontvreemde sieraden, worden afgeleid dat verdachte de sieraden heeft gestolen. In dit voorbeeld is de conclusie slechts waarschijnlijk en die volgt dus niet noodzakelijk uit de premissen. Anders dan Aristoteles is thans algemeen aanvaard dat de inductieve redenering niet verder voert dan een meer of mindere mate van waarschijnlijkheid.

Naast deductie en inductie lijkt Aristoteles nog een derde redeneervorm te onderkennen. Door Charles S. Peirce wordt deze vorm getypeerd als 'het aannemen van een hypothese, omdat deze reeds bekende feiten verklaart'. ${ }^{48}$ Hierbij baseert hij zich op een controversiële passage uit de Analytica priora over apagôgê, dat wordt vertaald als abductie of reductie. Kenmerkend voor abductie is dat de redenering begint vanuit 'wat er is' om tot de oorzaak ervan of enige andere verklaring te komen. ${ }^{49}$ Dat komt er in feite op neer dat bij de observatie van een gebeurtenis de meest voor de hand liggende verklaring wordt gekozen. Als bijvoorbeeld buiten op straat een plas met water ligt, zou je daaruit kunnen concluderen dat het heeft geregend. In het dagelijks bestaan maken we veelvuldig gebruik van dergelijke abducties. Om als mens te overleven en functioneren binnen een samenleving is enige abductie simpelweg onvermijdelijk. Dat geldt ook voor het recht, waarin deze redeneervorm een niet weg te denken creatieve rol vervult bij het formuleren van hypothesen voor nader onderzoek en het vergaren van nieuw bewijsmateriaal. Het grote gevaar is evenwel wanneer de abductieve redenering buiten de (Montreal/Kingston: McGill-Queen's University Press, 2009), 95-155, i.h.b. 119-20.

47 Aristoteles, Ethica Nicomachea, 1143 b 10-14.

48 Zie Charles S. Peirce, 'Types of Reasoning,' in Reasoning and the Logic of Things: The Cambridge Conferences Lectures of 1898, red. Kenneth L. Kettner (Cambridge, MA: Harvard University Press, 1992), 140.

49 Hendrik Kaptein, Logisch? Leren van drogredeneringen (Den Haag: Boom Juridisch, 2017), 155. 
'context van ontdekking' wordt gebruikt ter legitimatie van een hypothese. Anders dan inductie kan met behulp van abductie niets worden vastgesteld over de relevantie, betrouwbaarheid en bewijskracht van het bewijs in relatie tot de voorliggende hypothesen. ${ }^{50}$ Het is daarom onjuist om abductie te definiëren als 'inference to the best explanation', zoals in de literatuur dikwijls wordt gedaan. Abductie komt niet verder dan de vaststelling dat een verklaring voor voorhanden bewijsmateriaal kan worden geboden, waarmee andere verklaringen niet worden uitgesloten. ${ }^{51}$ Dit lijkt ook overeen te stemmen met de oorspronkelijke opvatting van Aristoteles, die stelt dat het resultaat hooguit geloofwaardig (pistós) is en derhalve zeer geschikt voor de retoricus als middel om te overtuigen. ${ }^{52}$

Uiteindelijk berust het rationeel proces van bewijzen aldus hoofdzakelijk op inductie en deductie. Het is van belang om te benadrukken dat beide redeneervormen twee zijden van dezelfde medaille zijn. Inductie geeft aanleiding tot deductie en omgekeerd. Daarbij staan de verschijnselen centraal; een uitspraak kan slechts voor waarheid doorgaan als zij overeenstemt met de verschijnselen. Of zoals Aristoteles het formuleert: waarheid is 'zeggen van dat wat is dat het is, en van dat wat het niet is dat het niet is'. ${ }^{53}$ Zo ook dient in een strafzaak te worden bewezen dat het tenlastegelegde overeenstemt met de historische werkelijkheid. Dit staat bekend als de correspondentietheorie van de waarheid, die als gezegd ook in rationele bewijstheorieën wordt aangehouden. Sinds Descartes heeft deze waarheidsopvatting en daarmee de conceptie van verschijnselen echter een wezenlijk andere invulling gekregen, die nog steeds doorklinkt in de manier waarop in het strafrecht naar bewijs wordt gekeken.

\section{De tweedeling van subject en object}

\subsection{Rationaliteit, objectiviteit en wetenschappelijkheid}

Descartes wordt vaak beschouwd als de vader van de moderne filosofie. Zijn magnum opus, Meditaties over de eerste filosofie, markeert een copernicaanse wending in het denken over kennis en wetenschap. Anders dan Aristoteles maakt Descartes uit de verschillende veelal tegenstrijdige opvattingen van filosofen en geleerden op, dat er niets is waaraan men niet kan twijfelen. ${ }^{54}$ Het bouwwerk van menselijke kennis mist bijgevolg een onwankelbare fundering, waar niet aan kan worden getornd. Descartes stelde zich daarom als doel om een onbetwistbaar uitgangspunt te vinden, waarop alle kennis is gegrond. Om dat te bereiken moeten we eerst al onze opvattingen afwijzen die zelfs maar in de geringste mate vat-

51 Hendrik Kaptein, 'Strijd om strafrechtelijke waarheid: deskundige inbreng van buiten blijft nog wel even belangrijk,' Expertise en Recht 3 (2009): 57.

52 In de klassieke vertaling van de Loeb Classical Library is pistós vertaald met 'probable'. De letterlijke vertaling is evenwel: reden of oorzaak om te geloven. Vgl. Mary P. Nichols, 'Aristotle's defence of rhetoric,' The Journal of Politics (1987): 663.

54 René Descartes, Over de methode (Amsterdam: Boom, 2002), 41-42 (origineel 8-9). 
baar zijn voor twijfel. ${ }^{55}$ Daarbij kunnen we volgens Descartes niet vertrouwen op onze zintuigen, omdat deze ons al meer dan eens hebben misleid. De ervaring is derhalve niet de bron van ware kennis zoals bij Aristoteles, want in laatste instantie kan alleen de ratio waarheid en zekerheid verschaffen. Verder dienen overhaaste of vooringenomen oordelen zorgvuldig te worden vermeden. ${ }^{56}$ Dat geldt eveneens voor waarheden die door de traditie of religie (endoxa) zijn overgedragen. Om de methodische twijfel te voltrekken zal men aldus, gelijk Descartes zijn lezers in het voorwoord van de Meditaties voorhoudt: 'zijn geest moeten afwenden van de zintuigen en van alle vooropgezette meningen. ${ }^{57}$

Door alles in twijfel te trekken kwam hij uiteindelijk tot de slotsom dat het noodzakelijk was dat hij, die dat dacht, bestaat. ${ }^{58}$ Met andere woorden: ik denk, dus ik ben (cogito, ergo sum). Dit inzicht is volgens Descartes boven elke twijfel verheven, omdat het is onthuld door het 'natuurlijk licht' van de rede. ${ }^{59} \mathrm{Op}$ basis van dit onwankelbare uitgangspunt creëerde hij een dichotomie tussen het bewustzijn en de wereld. De mens wordt gereduceerd tot een absoluut en geïsoleerd subject dat is opgesloten in de cocon van zijn eigen denken en daardoor volkomen is afgescheiden van de buitenwereld. Daarmee zadelde Descartes de wijsbegeerte op met een fundamenteel probleem, want hoe weet ik dat wat ik denk ook correspondeert met de werkelijkheid? De onaantastbare zekerheid van het cogito, ergo sum is voor Descartes evenwel het criterium en model van waarheid en kennis. Want alles wat op gelijke wijze door het natuurlijk licht wordt onthuld, is voor een ieder evident die 'helder en welonderscheiden' (clare et distincte) denkt. Daarom stelt hij als algemene regel dat alles wat we helder en welonderscheiden inzien waar is. ${ }^{60}$ De heldere en welonderscheiden begrippen vloeien niet voort uit de zintuiglijke ervaring van de wereld, maar zijn het gevolg van goddelijke interventie. We hebben deze begrippen bij geboorte van God meegekregen. En aangezien God in zijn oneindige goedheid ons nimmer zou bedriegen, kunnen we zonder meer vertrouwen op de waarachtigheid van het inzicht waarmee hij ons heeft uitgerust. ${ }^{61}$

Het domein van de heldere en welonderscheiden begrippen valt bij Descartes samen met wat hij de 'universele wiskunde' (mathesis universalis) noemt. ${ }^{62}$ Dit betreft een algemene methode, die de werkelijkheid reduceert tot wat in rationele wiskundige termen kan worden uitgedrukt. Kennis bestaat uit heldere en welonderscheiden begrippen van kwantiteit, die worden verkregen door te meten en te

55 René Descartes, Meditations on First Philosophy (Cambridge: Cambridge University Press, 1996), 12-15 (origineel 17-23).

56 Descartes, Over de methode, 49 (origineel 18).

57 Descartes, Meditations on First Philosophy, 8 (origineel 9).

58 Descartes, Over de methode, 61 (origineel 32) en in iets afwijkende vorm Meditations on First Philosophy, 17 (origineel 25).

59 Descartes, Meditations on First Philosophy, 26-27 (origineel 38-39).

60 Descartes, Meditations on First Philosophy, 24 (origineel 35) en Over de methode, 61 (origineel 33).

61 Descartes, Meditations on First Philosophy, 37-38 (origineel 54-55) en Over de methode, 62 (origineel 34).

62 Zie René Descartes, Regels om richting te geven aan het verstand en ander vroeg werk (Amsterdam: Boom, 2010), 10.377-8. 
rekenen. De essentie of objectiviteit van materiële dingen is voor Descartes derhalve de uitgebreidheid in de ruimte (res extensa), die is uitgestrekt in lengte, breedte, hoogte, afstand, gewicht enzovoort. De uitgebreidheid omvat met andere woorden de eerder genoemde brute facts van de natuur, waar de mens als denkend ding (res cogitans) buiten staat. Dit komt er in feite op neer dat de werkelijkheid objectief kan worden begrepen voor zover zij wordt benaderd vanuit de wis- en natuurkunde. Descartes is dan ook geen rationalist in de restrictieve zin van het woord, die dacht dat ware kennis louter door rationele reflectie kan worden verworven, volkomen onafhankelijk van de ervaring. Hij reduceert ervaring van de wereld evenwel tot de natuurwetenschappelijke observatie, die het mogelijk maakt om de aangeboren heldere en welonderscheiden begrippen van kwantiteit toe te passen op de uitgebreide objecten. Empirisch onderzoek en experimenten kunnen bijdragen aan het ontdekken van de objectieve werkelijkheid, mits dit onder de regie van de rede wordt uitgevoerd. ${ }^{63}$ De betekenis van rationaliteit, objectiviteit en wetenschappelijkheid krijgt met Descartes aldus een natuurwetenschappelijke duiding. ${ }^{64}$

\subsection{De Cartesiaanse revolutie in het strafrecht}

Tegenwoordig is in de wetenschap en het recht het ideaal van de positieve natuurwetenschappen nog steeds dominant. Daarbij wordt objectiviteit beschouwd als het correlaat van de onafhankelijke en onbevooroordeelde rede. Dat neemt evenwel niet weg dat de hang naar onbetwijfelbare en zekere kennis een tegenbeweging heeft opgeroepen, die het positivistische klimaat heeft veranderd. Onder invloed van het zogeheten antifunderingsdenken heeft de notie van een onwankelbaar fundament sinds de tweede helft van de vorige eeuw aan zeggenschap ingeboet. Volgens de antifunderingsdenkers is iedere aanspraak op kennis en waarheid per definitie historisch en contextgebonden. ${ }^{65}$ Dat brengt met zich dat er niet één type waarheid is, maar er diverse waarheden bestaan afhankelijk van het perspectief dat wordt gehanteerd. Deze opvatting heeft ook in de rechtswetenschappelijke literatuur duidelijke sporen nagelaten. ${ }^{66}$ Binnen de rationalistische traditie komt dit tot uitdrukking in de hiervoor aangehaalde vooronderstelling dat de beslisser reeds bij voorbaat is toegerust met een hoeveelheid generalisaties - society's stock of knowledge. Het proces van bewijzen voltrekt zich derhalve niet in een sociaal vacuüm, maar altijd vanuit een bepaalde (historische) context.

Zie Daniel Garber, Descartes Embodied. Reading Cartesian Philosophy through Cartesian Science (Cambridge: Cambridge University Press, 2004), 85-110, i.h.b. 109.

64 Zie ook Wilhelmus A.M. Luypen, Existentiële fenomenologie (Utrecht/Antwerpen: Het Spectrum, 1962), 164-65.

65 Zie Stanley Fish, Doing What Comes Naturally: Change, Rhetoric, and the Practice of Theory in Literary and Legal Studies (Durham: Duke University Press, 1989), 344-45.

66 Zie bijvoorbeeld Tineke P.M. Cleiren, 'Waarheid in het strafrecht: niet tot elke prijs,' in Het procesrecht en de waarheidsvinding, Preadvies vereniging voor procesrecht, red. Tineke P.M. Cleiren et al. (Den Haag: Boom Juridische uitgevers, 2001) en Nico J.M. Kwakman, 'De strafrechter en de deskundige. Over de waarheidscondities en waarheidsdefinities in het straf(proces)recht,' Rechtsgeleerd Magazijn Themis 5/6 (2010) en Jan H. Crijns en Patrick van der Meij, 'Over de grenzen van de materiële waarheidsvinding,' in Langs de randen van het strafrecht, red. Roelof H. Haveman et al. (Nijmegen: Wolf Legal Publishers, 2005). 
Desalniettemin blijven de rationele bewijstheorieën trouw aan het uitgangspunt dat kennis betrekking heeft op een externe werkelijkheid. ${ }^{67}$ Aangenomen dat iedere voorstelling van de werkelijkheid de echte waarheid slechts in meer of mindere mate kan benaderen, blijft de strafrechtelijke waarheidsvinding gekenmerkt door de Cartesiaanse tweedeling van werkelijkheid en bewustzijn. Bij het achterhalen van de materiële waarheid, dat wil zeggen wat zich werkelijk heeft afgespeeld, geldt als richtinggevend ideaal dat de rechter of officier van justitie de wereld zo veel mogelijk als neutrale waarnemer op afstand beschouwt, onafhankelijk van zijn subjectieve verlangens, motieven of vooroordelen. Meijers spreekt in dit verband van een 'mentale en dynamische onpartijdigheid, nodig om afweging en beslissing zoveel mogelijk te vrijwaren van de macht van eigen vooroordelen en eenzijdigheden, van welke aard ook'. ${ }^{68}$ Om te kunnen oordelen in overeenstemming met de materiële waarheid is het dus van belang dat de rechter en officier van justitie abstraheren van hun eigen gesitueerdheid. Dit is wat wordt bedoeld met objectieve waarheidsvinding en wat naar de eisen van magistratelijkheid van hen beiden wordt verwacht.

Hierbij geldt als leidend criterium dat het tenlastegelegde wettig en overtuigend bewezen moet kunnen worden. Anders gezegd, het in de tenlastelegging gestelde moet 'buiten redelijke twijfel' ondubbelzinnig uit het bewijsmateriaal kunnen worden afgeleid. ${ }^{69}$ Het Cartesiaanse pathos van twijfel is via de wetenschap ook het onderzoek in strafzaken gaan beheersen. Hoewel het beginsel in dubio pro reo teruggaat tot Aristoteles, is de twijfel eerst in het moderne strafrecht tot grondstemming geworden, die de waarheidsvinding en het bewijzen in het strafproces constant begeleidt. Voortdurend moeten allerlei hypothesen, beweringen en verklaringen in twijfel worden getrokken en belangen kritisch tegen elkaar worden afgewogen in het licht van de hoofddoelstelling van het strafprocesrecht: de juiste toepassing van het materiële strafrecht. Echter niet om uit te komen bij zekerheid, maar bij een hogere graad van waarschijnlijkheid. Waar het kantelpunt ligt dat het voorhanden wettige bewijs het tenlastegelegde dermate waarschijnlijk maakt dat de twijfel niet langer als redelijk kan worden aangemerkt, berust op de beredeneerde overtuiging (conviction raisonnée) van de beslisser. ${ }^{70}$ In tegenstelling tot de conviction intime moet de beslisser zijn overtuiging rationeel (kunnen) motiveren (lees: legitimeren) met behulp van de deductieve en inductieve redenering. ${ }^{71}$ Dit is in zekere zin verwant aan het helder en welonderscheiden inzicht, voor zover ook hier de kritische rationele reflectie van het subject als onafhankelijke en onpartijdige waarnemer garant staat voor de objectiviteit van de beslissing.

67 Twining, Rethinking Evidence, 110.

68 Zie Leo C.M. Meijers, 'Ethische dilemma's van het openbaar ministerie,' in Ethiek en het juridisch beroep, red. Leny E. de Groot-Van Leeuwen et al. (Den Haag: VUGA, 1995), 134-35.

69 Zie J.F. Nijboer, Strafrechtelijk bewijsrecht (Nijmegen: Ars Aequi Libri, 2011), 73.

70 Zie ook Johannes F. Nijboer, Strafrechtelijk bewijsrecht (Nijmegen: Ars Aequi Libri, 2011), 74.

71 Vgl. Wilma H.B. Dreissen, Bewijsmotivering in strafzaken (Den Haag: Boom Juridische uitgevers, 2007), 8. 
Volgens Descartes kunnen evenwel alleen begrippen van kwantiteit helder en welonderscheiden worden gedacht. Het getal is de sleutel om de werkelijkheid of objectiviteit van de wereld te onthullen. In de context van strafrechtelijke waarheidsvinding en bewijsvoering is de reikwijdte van het objectiverende kennen daarentegen breder. Immers zijn de resultaten van 'kwalitatief' onderzoek, zoals verklaringen en niet-technische processen-verbaal onmisbaar en vormen een substantieel - en dikwijls uitsluitend - onderdeel van het strafdossier. Dat neemt niet weg dat grote waarde wordt gehecht aan kwantitatieve onderzoeksresultaten en deze een steeds prominentere rol krijgen toebedeeld. Dit heeft onder meer te maken met de wetenschappelijke vooruitgang en daarmee gepaard gaande technische ontwikkelingen, die de mogelijkheden van forensisch onderzoek hebben verruimd. In diepere zin houdt het toegenomen belang van kwantitatieve gegevens echter verband met wat Martin Heidegger veelzeggend typeert als het 'rekenende denken'. ${ }^{72}$ Dit behelst het denken van de wetenschappen, die de werkelijkheid bevragen in het licht van zijn berekenbaarheid, bruikbaarheid en beheersbaarheid. Ieder gebeuren, elk verschijnsel wordt teruggebracht tot een res extensa, die met behulp van het verstand wordt geordend en verklaard. Als zodanig verraadt het rekenende denken een fundamentele behoefte aan zekerheid en veiligheid; het wil precies weten wat een 'ding' behelst. ${ }^{73}$ Ook in de strafprocedure is deze denkwijze omnivalent, waarbij men op technische wijze zoekt naar opheldering en positieve verklaringen voor zover dat juridisch relevant is. In dit licht kan eveneens de toegenomen belangstelling voor de Bayesiaanse bewijstheorie worden uitgelegd. Binnen het forensisch domein en in de wetenschappelijke literatuur wordt deze theorie steeds meer beschouwd als de gouden standaard voor de evaluatie van bewijs. ${ }^{74}$ Daarbij is de objectivering van bewijs het parool, dat wil zeggen het streven naar het rapporteren van een goed onderbouwd getal als maat voor de bewijskracht (likelihood ratio), dat zo min mogelijk afhankelijk is van de deskundige. ${ }^{75}$ Meten is weten, dus 'zonder statistiek geen bewijs'. ${ }^{76}$

\section{Herwaardering rationalistische bewijsopvatting}

\subsection{Terug naar de zaken zelf}

Sinds Descartes wordt het kennen bepaald als een dualistische betrekking tussen het subject en een daarvan losgescheurd object. Dit heeft in de moderne filosofie geleid tot een heropleving van het aloude schijn-en-zijn-paradigma. ${ }^{77}$ De wereld

72 Zie Martin Heidegger, Gelatenheid (Tielt: Lannoo, 1979), 33-34 (origineel 12-13).

73 Zie ook Ronald P. Buckley, 'Martin Heidegger: The "End” of Ethics,' in Phenomenological Approaches to Moral Philosophy: A Handbook, red. John J. Drummond et al. (Dordrecht: Springer Science + Business Media, 2013), 219.

74 Zie de vakbijlage 'Interdisciplinair forensisch onderzoek' van het Nederlands Forensisch Instituut, te raadplegen op www.nfi.nl.

75 Marjan Sjerps, 'Bewijskracht 10, volle vaart recht vooruit' (Oratie, Amsterdam, UvA, 2011), 15-16.

76 Vgl. Sjerps, 'Bewijskracht 10, volle vaart recht vooruit', 6.

77 Vgl. Theo de Boer, 'Fenomenologie, een lied van schijn en wezen,' in Filosoferen. Gangbare vormen van wijsgerig denken, red. Remigius C. Kwant et al. (Alphen aan den Rijn: Samsom, 1977), 76. 
werd in tweeën gedeeld in een subjectieve uitwendige wereld van de verschijning waarachter de objectieve inwendige wereld van de wetenschap schuilgaat. Friedrich Nietzsche noemde dat smalend de waan van de achterwerelden, want volgens hem is er geen binnen en buiten in de wereld, maar alleen de ervaring van het menselijk leven in wording. ${ }^{78}$ De schijn verhult de ware of echte werkelijkheid niet, hij onthult dat. ${ }^{79}$ In de concrete ervaring toont de wereld zijn menselijk gelaat en laat zij zich werkelijk kennen. Zoals ook Søren Kierkegaard benadrukt is elk wezenlijk kennen van het bestaande betrokken op het existerende subject. ${ }^{80}$ Het is onmogelijk om het subject en de wereld los van elkaar te denken, omdat zij elkaar wederzijds impliceren. Het bewustzijn van de mens is dus geen archimedisch gezichtspunt van waaruit de wereld, volkomen onafhankelijk van onze eigen gesitueerdheid of levensomstandigheden, kan worden aanschouwd. Bewustzijn is wezenlijk intentionaliteit; gericht op de wereld. Volgens Heidegger is de grondgesteldheid van het zijn van de mens (erzijn) daarom het 'in-de-wereld-zijn'. ${ }^{81}$ Elk begrip van de wereld veronderstelt en is gerelateerd aan het existerend subject en omgekeerd.

Dit is in het kort wat men het fait primitif van de existentiële fenomenologie is gaan noemen. ${ }^{82}$ De fenomenologie staat voor een filosofische methode en beweging die, zoals de benaming doet vermoeden, de fenomenen als studieobject heeft. Zij kent meerdere scholen en stromingen, waarvan de existentiële fenomenologie er één is. Met de term fenomeen wordt gemeenschappelijk gedoeld op datgene wat in de concrete ervaring aan het bewustzijn verschijnt. Fenomenologen willen de fenomenen beschrijven zoals ze in het alledaagse leven worden ervaren, voordat ze zijn onderworpen aan theoretische bespiegelingen. De fenomenologie wordt dan ook vaak gekarakteriseerd met de maxime 'terug naar de zaken zelf'. Dat vergt een vorm van transcendentaal redeneren, waarin alles wat ons afleidt van de zaken zelf, zoals vaste denkgewoonten, gevestigde ideeën of vooringenomen voorstellingen van de wereld, 'tussen haakjes wordt gezet'. Volgens de vader van de fenomenologische methode, Edmund Husserl, dienen we ons oordeel over de ware werkelijkheid op te schorten, teneinde ons aandachtig te richten op de concrete ervaring van de verschijnselen. Dit opschorten (epoché) wordt ook wel fenomenologische reductie genoemd. Het gaat om een teruggaan en stilstaan bij de fenomenen. In dit opzicht benadrukt de existentiële fenomenologie, in tegenstelling tot andere richtingen binnen de fenomenologie, de prioriteit van het prereflectieve domein boven het reflectieve domein. ${ }^{83}$ Niet het

78 Zie Friedrich Nietzsche, Aldus sprak Zarathoestra (Amsterdam: Boom, 2006), 34-36 en Friedrich Nietzsche, Menselijk, al te menselijk (Amsterdam: De Arbeiderspers, 2008), 28-30.

79 Vgl. Jean-Paul Sartre, Het zijn en het niet. Proeve van een fenomenologische ontologie (Rotterdam: Lemniscaat, 2010), 28.

80 Zie Søren A. Kierkegaard, 'Afsluitend wetenschappelijk naschrift tot de wijsgerige kruimels,' in Denken en zijn, red. R. Petersen (Meppel/Amsterdam: Boom, 1982), 49.

81 Zie Martin Heidegger, Zijn en tijd (Nijmegen: Sun, 2013) 80 (origineel 53).

82 Zie ook Luypen, Existentiële fenomenologie, 46.

83 Zie Felicity Joseph en Jack Reynolds, 'Existentialism, Phenomenology and Philosophical Method,' The Bloomsbury Companion to Existentialism, red. Felicity Joseph et al. (London: Bloomsbury, 2014), 18. 
reflexief bewustzijn van de onafhankelijke waarnemer, maar de ongereflecteerde omgang met mensen en dingen (irréfléchi) is het fundamentele vertrekpunt. ${ }^{84} \mathrm{Het}$ objectiverende kennen is dan ook slechts een afgeleide van de ongereflecteerde ervaring van het leven in wording dat het primaire blikveld van het in-de-wereldzijn vormt. Dat roept de meer concrete vraag op hoe dat blikveld er feitelijk uitziet.

\subsection{Het in-de-wereld-zijn als verstaan}

Volgens Heidegger is onze verhouding tot de wereld in de eerste plaats praktisch van aard. De meest nabije wereld van de mens toont zich in de gemiddelde alledaagse omgang met dingen door ze te gebruiken als gereedschap of gebruiksvoorwerp om te kunnen voorzien in onze dagelijkse behoeften. Heidegger spreekt daarom over de mens in termen van 'er-zijn' dat geen scherp afgebakende essentie heeft, maar telkens wordt gedefinieerd door zijn activiteiten en bezigheden. ${ }^{85}$ Het er-zijn wordt bepaald door de mogelijke manieren om te zijn gezien de situatie waarin het zich bevindt. Kenmerkend voor de alledaagse omgang in de omringende wereld, is dat dingen ons tegemoet treden als 'iets om te.... ${ }^{86}$ In de woorden van Heidegger: de dingen manifesteren zich als terhande (werk)tuigen. Zo maak ik gebruik van een computer om dit artikel te kunnen schrijven en heb ik een bureau om de computer daarop te kunnen zetten. Achter die structuur van het 'om te' gaat een verwijzing van iets naar iets schuil; computer, bureau, stoel, lamp, kamer, vensters enzovoort. ${ }^{87}$ Als zodanig bestaat de wereld uit een onuitgesproken samenhangend geheel van verwijzingen, dat uiteindelijk verwijst naar onszelf en dat maakt dat we ons thuis voelen in de wereld. Het begrijpen van de wereld is aldus tegelijkertijd een zelfverstaan; het is altijd een mogelijkheid van jezelf dat in het begrijpen tot uitdrukking komt. In tegenstelling tot het theoretische kennen behelst het in-de-wereld-zijn een praktisch soort weten hoe met dingen om te gaan, hoe ze op de juiste manier te gebruiken en hoe je je dagelijkse bezigheden moet verrichten. ${ }^{88}$ Dit roept een associatie op met de praktische wijsheid (phronêsis) van Aristoteles, dat eveneens een op de concreetheid van de praktische situatie betrokken begrijpen omvat. Wanneer ik bijvoorbeeld mijn studeerkamer binnenloop, zie ik niet een kamer waarin de dingen zich ieder voor zich tonen, maar zie ik een kamer in dit huis die ik gebruik om in te lezen en schrijven. Ik sta nauwelijks stil bij de afmetingen of de plaats die de ruimte inneemt in het huis. Ik kijk naar het plafond; dat is niet alleen maar egaal wit, maar ook het plafond dat ik zelf heb geschilderd. Ik denk terug aan de verhuizing en het werk dat het heeft gekost om de kamer te schilderen. De kamer beschouw ik derhalve niet eerst thematisch, maar zij verdwijnt ongemerkt in een betekenisvol verwijzingsgeheel, dat het stempel draagt van mijn bezigheden en behoeften. 
In het alledaagse bestaan zijn we ons niet of vaag bewust van de verwijzingen, omdat we zelf opgaan in onze activiteiten of werkzaamheden. Pas bij een verstoring van de verwijzing, wanneer het tuig onbruikbaar blijkt te zijn voor het gestelde doel en derhalve niet langer geschikt is 'om te...', wordt de verwijzing expliciet. ${ }^{89}$ Denk aan de computer die niet meer opstart of de deur die niet meer sluit. Het tuig treedt dan vanuit de omringende context van het verwijzingsgeheel op de voorgrond als een afzonderlijk onbruikbaar object. Het mist evenwel nog niet iedere terhandheid, alsof het een ding is dat zo maar ergens voorkomt, want het blijft verbonden met onze alledaagse omgang in de zin dat het moet worden gerepareerd of weggegooid. ${ }^{90}$ Dat geldt daarentegen niet voor het rekenende denken van de wetenschap, waarin de dingen worden losgerukt uit hun omringende context van verwijzingen en volledig worden opgevat als iets voorhandens. Dat wil zeggen, als een uitgebreid object dat voor ons ligt en onbevooroordeeld kan worden beschreven onafhankelijk van menselijke doelen en activiteiten. ${ }^{91}$ Bijgevolg negeert of verwaarloost het rekenende denken dat ieder theoretisch of objectiverend kennen per definitie is ingebed in de praktische kennis die ontspruit aan de ongereflecteerde alledaagse omgang met mensen en dingen. De betekenisvolle samenhang van verwijzingen, die de wereld voor het er-zijn bekend en vertrouwd maakt, vormt met andere woorden de basisvoorwaarde en achtergrond die het überhaupt mogelijk maakt dat iets als voorhanden kan worden beschouwd.

Het praktisch begrijpen dat de ervaring van het in-de-wereld-zijn wezenlijk kenmerkt, fungeert in die zin als de voorstructuur van het verstaan dat iedere rationele reflectie begeleidt. Dit staat ook wel bekend als de hermeneutische ${ }^{92}$ cirkel, die zegt dat het grotere geheel beïnvloedt hoe we delen daarvan verstaan. De volgende aan de theoloog Rudolf Bultmann toegedichte omschrijving vat deze notie treffend samen: 'Menselijk begrijpen wordt gestuurd door het voor-verstaan, dat is afgeleid van de concrete existentiële situatie, en dat voor-verstaan verschaft het raamwerk en de parameters waarbinnen elke interpretatie plaatsvindt. ${ }^{93}$ Hier moet aan worden toegevoegd dat dit voor-verstaan per definitie historisch van aard is, dat maakt dat we zijn verbonden met de traditie en cultuur waarin we zijn geworteld. Deze band met de geschiedenis conditioneert onze persoonlijke gesitueerdheid op zo'n fundamentele wijze, dat we er nooit volledig vat op kunnen krijgen of aan kunnen ontsnappen. We bevinden ons altijd midden in de geschiedenis. 'Een mens lijkt daarom nooit meer op de allereerste mens. Hij begint het bestaan op een specifiek niveau dat een opeenstapeling is van alles wat vooraf ging. ${ }^{94}$ Wie iets wil begrijpen is dus onvermijdelijk blootgesteld aan vooropgezette meningen, die vanuit het verleden binnen de traditie worden overgeleverd

89 Zie Heidegger, Zijn en tijd, 106 (origineel 74-75).

90 Zie Heidegger, Zijn en tijd, 104 (origineel 73).

91 Zie ook Samuel IJsseling, Denken en danken. Geven en zijn (Nijmegen: Vantilt, 2015), 28.

92 De hermeneutiek is afgeleid van het Griekse hermêneutikê technê dat staat voor: vaardigheid in het interpreteren.

93 Zie Jean Grondin, Introduction to Philosophical Hermeneutics (New York: Yale University Press, 1994), 92.

94 José Ortega y Gasset, De opstand van de massamens (Rotterdam: Lemniscaat, 2016), 62. 
en waardoor men vanuit bepaalde verwachtingen anticipeert op de betekenis. ${ }^{95}$ Wanneer ik bijvoorbeeld een boek wil lezen over DNA-bewijs, heb ik reeds bepaalde impliciete verwachtingen over wat DNA is en hoe dat wordt gebruikt in het strafrechtelijk onderzoek. Tijdens het lezen worden die verwachtingen voortdurend bevestigd en herzien. Dit gebeurt veelal op de achtergrond - achter de coulissen van de rationele reflectie - waardoor verwachtingen onbewust beïnvloeden hoe ik de tekst begrijp. Hans-Georg Gadamer pleit in dit kader voor een rehabilitatie van de vooroordelen, waarmee hij zich verzet tegen het door Descartes geïnspireerde verlichtingsideaal dat iedere vorm van vooringenomenheid afwijst. Bij interpretatie komt het er volgens Gadamer niet op aan om de eigen vooropgezette meningen en vooroordelen uit te wissen en inhoudelijke neutraliteit na te streven, maar dat men zich bewust wordt van zijn vooringenomenheid door zijn persoonlijke existentiële situatie doorzichtig te maken. Op die manier kan de 'zaak zelf' - dat wil zeggen het voorliggende onderwerp - in zijn anders-zijn naar voren treden en krijgt het de mogelijkheid 'zijn inhoudelijke waarheid tegen de vooropgezette mening uit te spelen'. ${ }^{96}$

Deze waarheid onthult in zekere zin de objectiviteit van de werkelijkheid in relatie tot de interpreet. Eerst door de voorstructuur van het verstaan aan de verborgenheid te ontrukken en op de voorgrond te plaatsen, leert de interpreet welke vooropgezette mening is toegesneden op de zaak zelf. Zonder dit proces van 'ontsluiering' bestaat het gevaar dat de interpretatie wordt bezoedeld door 'de willekeur van invallen en de beperktheid van ongemerkt ingesleten denkgewoonten' ${ }^{97}$ De interpreet moet zich echter altijd laten leiden door de zaken zelf en heeft daarom de nimmer aflatende taak om te toetsen of de vooroordelen, die als verwachtingen (veelal ongemerkt) vooruitlopen op de betekenis van de zaak, beantwoorden aan de zaak zelf of moeten worden bijgesteld. Anders gezegd: objectiviteit is niet het correlaat van een onafhankelijke en onbevooroordeelde rede, maar van een existentiële rede die gericht is op het herkennen van de eigen vooroordelen en de kritische uitwerking daarvan, opdat deze niet onbewust doorwerken in de interpretatie en daarmee het eigene van de zaak zelf verbergen.

De klassieke aristotelische definitie van waarheid als de overeenstemming van een uitspraak met de verschijnselen, kan daarom het beste worden uitgelegd vanuit het 'bewust existeren'. ${ }^{98}$ Dat wil zeggen een dialoog tussen de interpreet en de zaak zelf, waarbinnen de waarheid wordt gevonden. Het uitspreken van die dialoog noemt Gadamer de dialectiek van vraag en antwoord. ${ }^{99}$ Want de verwachtingen over de betekenis van bijvoorbeeld een tekst presenteren zich eigenlijk als vragen, waarop in die tekst een antwoord wordt gevonden. Vanuit de persoonlijke

Zie ook Hans-Georg Gadamer, Waarheid en methode. Hoofdlijnen van een filosofische hermeneutiek (Nijmegen: Vantilt, 2014), 256.

96 Zie Gadamer, Waarheid en methode, 258.

97 Zie Gadamer, Waarheid en methode, 256.

98 Zie Martin Heidegger, Over het wezen van de waarheid (Budel: Damon, 2001), 73-74 (origineel 190-91).

99 Gadamer, Waarheid en methode, 352-61. 
historische situatie van het moment stelt de interpreet eigentijdse vragen aan de tekst, die het begrip daarvan reeds van tevoren bepalen. Het begrijpen van iets (tekst, gebeurtenis of persoon) betekent dus dat we het op zodanige wijze op onze situatie betrekken, dat we daarin antwoorden op onze vragen ontdekken.

\section{Hermeneutisch begrijpen van bewijs}

De hiervoor beschreven uitwerking van de fenomenologische oproep om terug naar de zaken zelf te gaan, schuurt dicht aan tegen Aristoteles' conceptie van de verschijnselen. Ook bij Aristoteles wordt het primaat toegekend aan de alledaagse omgang met mensen en dingen, waarin de wereld concreet verschijnt aan en doorgaans wordt ervaren door ieder willekeurig persoon. De verschijnselen komen daarom volgens hem tot uitdrukking in de gangbare opvattingen en overtuigingen; in wat gewoonlijk over een onderwerp wordt gezegd. Wie de werkelijkheid wil leren kennen zal zich dus moeten richten op het verzamelen en beschrijven van de endoxa. Dit komt eigenlijk neer op de vooropgezette meningen en vooroordelen, die de voorstructuur van het menselijk verstaan uitmaken. Anders dan wat Descartes voorhoudt is de traditie geen obstakel dat overwonnen moet worden. De mens is immers onderworpen aan de geschiedenis en weet zich derhalve als vanzelfsprekend opgenomen in een traditie en cultuur. Wat binnen de traditie gangbaar is laat zich aldus gelden als een voor-verstaan, dat onze blik op de werkelijkheid kleurt. Hoewel Aristoteles nog niet doorzag dat al het begrijpen wordt geleid door een voor-verstaan, zag hij wel in dat de zoektocht naar ware kennis wordt aangedreven en begrensd door de verschijnselen, oftewel de op concrete ervaring gebaseerde meningen. Dat betekent dat het begrijpen betrokken moet blijven bij de wijze waarop mensen dagelijks leven. De methode van Aristoteles om kennis te verwerven en de fenomenologische methode hangen dus met elkaar samen.

Dit werpt een interessant licht op de toepassing van deductie en inductie in het kader van het strafrechtelijk bewijzen. De selectie en waardering van bewijs in strafzaken is onverbrekelijk gebonden aan het voor-verstaan van de beslisser dat daaraan richting geeft. De persoonlijke historische situatie van de beslisser beïnvloedt dus hoe hij het bewijsmateriaal begrijpt en hiermee omgaat. Sterker nog, zonder vooropgezette meningen of vooroordelen zou het voor de beslisser überhaupt onmogelijk zijn om het bewijs te kunnen begrijpen. Reeds voordat kennis wordt genomen van het procesdossier en de tenlastelegging, stapt men met allerlei verwachtingen op een strafzaak af. Wanneer de rechter bijvoorbeeld begint aan de voorbereiding van een zaak met betrekking tot dood door schuld in het verkeer, heeft hij reeds een algemeen idee van de inhoud en maakt hij onbewust een schier oneindig aantal verwijzingen. Motorrijtuigen, weg, verkeerslichten, botsing enzovoort. Tijdens het lezen van het procesdossier worden de bepaalde verwachtingen over de betekenis van de afzonderlijke bewijsmiddelen in het licht van het geheel (tenlastelegging) continu bevestigd of herzien. De rechter wordt op deze manier blootgesteld aan dwaling door willekeurige invallen of ingesleten denkge- 
woonten die niet door de bewijsmiddelen zelf wordt gestaafd. Stel dat het procesdossier verhandelt over een aanrijding op een kruispunt, dan zal de rechter bij de interpretatie en uitleg van het bewijs ook zijn eigen kennis en ervaring met kruispunten of soortgelijke zaken betrekken, die eventueel niet op het voorliggende geval zijn toegesneden. Het voor-verstaan kan zo ongemerkt doordringen in de betekenis van het bewijs en daarmee een ondeugdelijke bewijsredenering in de hand werken. Bij de inductie en deductie wordt dan immers uitgegaan van onjuiste premissen.

Wie dus wil begrijpen wat het voorhanden bewijsmateriaal te zeggen heeft, heeft vooreerst de hermeneutische taak om zich bewust te maken van zijn eigen historiciteit door de persoonlijke vooropgezette meningen te herkennen en kritisch uit te spelen tegenover de inhoudelijke waarheid van het bewijs. Dat betekent dat de interpreet niet onmiddellijk vertrouwt op de vooroordelen waarvan hij niet weet dat hij ze heeft, maar hun legitimiteit ter discussie stelt, dat wil zeggen te bevragen op hun geldigheid en herkomst. Hierbij gaat het er nadrukkelijk niet om dat de interpreet zich probeert los te breken uit de traditie waarin hij is ingebed. Dat is een heilloze weg nu immers ieder begrijpen altijd tegelijk een zelfverstaan impliceert; de betekenis van het bewijs kan met andere woorden nooit los worden gezien van de situatie waarin de interpreet zich bevindt (in-de-wereld-zijn). We kunnen er daarentegen wel naar streven om de betekenisverwachtingen waarmee we naar het bewijs toestappen niet gedachteloos te voltrekken, maar ze naar de voorgrond te halen en te controleren en daardoor vanuit 'de zaak zelf' het juiste begrip te verkrijgen. Zo leidt elk begrijpen van bewijs tot een correctie van de eigen vooroordelen. Deze ervaring ligt aan het hart van wat ik bedoel met hermeneutisch begrijpen van bewijs.

De tentatieve aard van het begrijpen van bewijs staat voorts in een directe verhouding tot de idee van het recht als open systeem. De betekenissen van de in de tenlastelegging vervatte wetstermen zijn geen definitieve of gestolde begrippen, maar krijgen telkens in de toepassing op de concrete situatie nader vorm. Door de eigen vooroordelen kritisch uit te werken wordt de algemene betekenis van de wet niet onbewust bepaald door het rechtsbegrip waar de beslisser op dat moment reeds op voorhand van uitgaat, zodat de wet in haar uitleg op het voorliggende geval geconcretiseerd kan worden. ${ }^{100}$ Dat veronderstelt dat in iedere strafzaak aan de hand van het voorliggende bewijsmateriaal telkens opnieuw en anders moet worden beoordeeld of het tenlastegelegde kan worden bewezen en of dit een strafbaar feit oplevert. De wet draagt immers noodzakelijkerwijs een algemeen karakter en kan derhalve onmogelijk de eindeloze hoeveelheid gevallen bevatten die de praktische werkelijkheid in haar weerbarstige concreetheid presenteert. Elke nieuwe zaak vraagt in die zin om een op maat gesneden oordeel over wat de wet, tenlastelegging en het bewijs betekenen, waarin de persoonlijke historische gesitueerdheid van de beslisser kritisch is opgenomen. In dit licht moet ook de rechtsmethodologie van Paul Scholten worden uitgelegd: 'iedere

100 Zie ook Thomas J. de Jong, 'De zijnsgesteldheid van het recht. Over rechtsbegrip en de verantwoordelijkheid van de rechtsbeoefenaar,' Ars Aequi (2016): 429-30. 
beslissing, ook die welke zogenaamd naar de woorden geschiedt, is tegelijk toepassing en schepping; er is altijd het oordeel van hem, die beslist, dat mede de toepassing bepaalt. Dat volgt reeds uit de aard der toepassing zelf. ${ }^{101}$ Hier tekent zich de hermeneutische relevantie van het denken van Aristoteles nogmaals duidelijk af. Het betreft in dit verband de eerder aangehaalde praktische wijsheid (phronêsis). De beslisser die aan een voorliggend geval recht wil doen mag niet van de concrete praktische situatie waarin hij zich bevindt abstraheren. Wil hij weten wat de wet en het beschikbare bewijsmateriaal in dit geval van hem verlangen, dan moet hij beide kritisch op zijn eigen situatie betrekken. ${ }^{102}$

Uit het voorgaande zou men kunnen opmaken dat de hermeneutische conceptie van het vooroordeel samenvalt met de onbewuste doorwerking van feiten en omstandigheden van algemene bekendheid of algemene ervaringsregels. Het voor-verstaan vanuit de traditie komt dan min of meer neer op 'background knowledge' of 'society's stock of knowledge'. Deze conclusie gaat echter maar ten dele op. Het klopt dat impliciete generalisaties de interpretatie en evaluatie van bewijs als vooropgezette meningen beïnvloeden. In dit opzicht vinden alle rationele bewijstheorieën aansluiting bij de hermeneutische taakstelling, waarbij ze elkaar kunnen aanvullen. De theorie van verhaal en verankering is door zijn holistische benaderingswijze zeer geschikt om de betekenis van de afzonderlijke bewijsmiddelen vast te stellen op basis van een overkoepelend en coherent verhaal. Daarnaast kan de argumentatietheorie bij uitstek worden ingezet om de redenering door te lichten op verkeerde gevolgtrekkingen of onjuiste aannamen en kan met behulp van het Bayesiaanse model de probabiliteit van de bewijsmiddelen berekend worden.

Het is evenwel van wezenlijk belang om het hermeneutisch begrijpen van bewijs te onderscheiden van het redeneren en argumenteren zoals in de bewijstheorieën wordt voorgestaan. De hermeneutische cirkel van het verstaan brengt met zich dat het voor-verstaan al het begrijpen determineert en limiteert. Het vooroordeel is derhalve niet een irrationele dwaling van de geest die het proces van bewijzen ondermijnt, maar conditioneert dat proces op een ontologische wijze. Anders dan wat de bewijstheorieën veronderstellen, bestaat tussen de beslisser die over het bewijs heeft te oordelen en de externe werkelijkheid geen kloof die overbrugd moet worden. Het persoonlijk begrijpen van bewijs en de verschijnselen waarop het betrekking heeft zijn onafscheidelijk. Het vooroordeel heeft in die zin een diepere betekenis en bredere strekking dan onuitgesproken feiten en omstandigheden van algemene bekendheid of algemene ervaringsregels. De generalisaties die op de achtergrond actief zijn fungeren niet slechts als waarborgen of ankers die als een bindmiddel het bewijs aan een verhaal/argument/hypothese verbinden, maar behoren toe aan de verwachtingshorizon die het begrijpen van bewijs en daarmee het proces van bewijzen mogelijk maakt.

101 Scholten, Handleiding tot de beoefening van het Nederlands burgerlijk recht, 76 .

102 Zie ook Gadamer, Waarheid en methode, 298-309, i.h.b. 309. 
Daar komt bij dat met iedere ervaring van het in-de-wereld-zijn - zij het een gebeurtenis, persoon, tekst of kunstwerk - het voor-verstaan wordt toegepast en tegelijk veranderd. 'De nieuwe ervaring brengt alles aan het wankelen wat onze verwachtingen heeft geleid en voegt zichzelf daarbij in een nieuwe ordening in', aldus Gadamer. ${ }^{103}$ Dat betekent dat een rechter die toevallig een boek heeft gelezen over DNA-bewijs met andere verwachtingen een rapportage over DNA-onderzoek leest dan iemand die dit boek niet gelezen heeft, net zoals zijn eigen persoonlijke ervaringen als verkeersdeelnemer de interpretatie van een technisch onderzoek van de Verkeersongevallenanalyse (onbewust) beïnvloeden. Het gaat hier om de empeiria in de fenomenologische zin van het woord; de alledaagse ervaring van de verschijnselen die is ingebed in de omhullende betekenissamenhang van de historische traditie. Het voor-verstaan is dus een veel rijker begrip dan wat de Hoge Raad verstaat onder feiten en omstandigheden van algemene bekendheid of algemene ervaringsregels. Het omvat de historische realiteit van de beslisser.

\section{Conclusie}

In deze bijdrage heb ik gepoogd een hermeneutische visie op het proces van bewijzen in strafzaken te formuleren. Daarin staat het gesitueerd begrijpen van bewijs centraal, dat is gebaseerd op een existentieel-fenomenologische analyse van inde-wereld-zijn en aansluit bij het oorspronkelijke gedachtegoed van Aristoteles over redeneren en argumenteren. Volgens deze analyse vormen de mens en de wereld een onverbrekelijke eenheid, waarin beide termen elkaar wederzijds impliceren. Hiermee wordt stelling genomen tegen het Cartesiaanse dualisme dat de mens isoleert van een externe werkelijkheid, waardoor de materiële waarheidsvinding in strafzaken en derhalve het proces van bewijzen in sterke mate wordt bepaald. Hoewel binnen het wetenschappelijk en juridisch discours breeduit wordt onderkend dat waarheidsvinding per definitie historisch en contextgebonden is, blijft een zo veel mogelijk onafhankelijk en onbevooroordeeld vaststellen van de waarheid het vigerende ideaal. Dit draagt ook bij aan de redelijke kern van rationele bewijstheorieën. Vanuit het hermeneutische perspectief heb ik allereerst een alternatieve beschrijving willen geven van het proces van bewijzen, dat in tegenstelling tot de bewijstheorieën aanvangt in het prereflectieve domein van het voor-verstaan. Dit betreft vooral een pleidooi voor het vooroordeel, dat elke vorm van begrijpen onontkoombaar kenmerkt. De concrete historische situatie waarin de beslisser is ingebed is dus geen beperking, maar de condicio sine qua non die het begrijpen van bewijs mogelijk maakt. Het proces van bewijzen moet er daarom niet op zijn gericht om vooroordelen te vermijden, maar juist om ze te onthullen en kritisch uit te werken. Op deze wijze wordt voorkomen dat ze onbewust de interpretatie en evaluatie van het voorhanden bewijsmateriaal beïnvloeden en kan vastgesteld worden welke vooroordelen wel en vooral niet zijn toegesneden op de zaak zelf. De rationele bewijstheorieën kunnen daarbij behulpzaam 
zijn, waarin de vooroordelen onder andere schuilgaan onder de mantel van onuitgesproken feiten of omstandigheden van algemene bekendheid of algemene ervaringsregels. 